\title{
SLOW AND QUICK VIOLENCE \\ Illnesses and Injuries in America Is in the Heart
}

\author{
Ling Liu \\ International Business School, South China Normal University \\ lliu@ibc.scnu.edu.cn
}

\begin{abstract}
This article aims to offer a new route into the study of Carlos Bulosan's America Is in the Heart by going beyond the usual sociocultural focus and turning instead to the material, specifically the illnesses and injuries borne by Filipino bodies-tuberculosis, syphilis, hunger, injuries, even death-to learn about their colonial and migrant experiences. In the novel, tuberculosis affects working-class migrant Filipinos disproportionately in both the Philippines and the United States of America. Migrant Filipinos are also constantly haunted by hunger and are always injured, or even shot; and working-class women frequently die from syphilis. Applying ecocritical theories to study the entanglement between the novel's material and social environment, this article argues that human bodies are socialized bodies: the Filipino characters' bodily illnesses and injuries are testimony to the cruel social injustices they have suffered. This article further uses Rob Nixon's concept of "slow violence" to argue that tuberculosis, syphilis, and hunger are manifestations of the slow violence that bring into light the hidden cost of colonialism, racism, sexism, and class oppression, while images of shot or beaten Filipino bodies are "quick violence" that force us to face the bloodiness of racial oppression directly. Lastly, this article examines where healing and hope for resistance lie.
\end{abstract}

\section{Keywords}

ecocriticism, body, slow violence, sexuality, racialization, COVID-19

\section{About the Author}

Ling Liu received her master's degree in English Literature from the George Washington University in Washington, DC. Her research interests are ecocriticism, postcolonial literature, Asian diasporic literature, and disability studies. She is currently working on the literary representation of bodily pains and environmental degradation in the works of Carlos Bulosan, Ruth Ozeki, and Chen Qiufan. She works as a teaching assistant at the International Business School in South China Normal University. She has participated in conferences like Composing Disability at the George Washington University and Beyond Borders: Empires, Bodies, Science Fictions with the London Science Fiction Research Community. 
CNN anchor Chris Cuomo is one of the first few COVID-stricken celebrities to share his fight against the virus. In CNN's report, he gives a visceral description of the pain he experienced: "The beast comes at night ... As we know the health care workers have taken to call the virus 'the beast.' I understand why. My fever has gone up a couple of degrees in like the last thirty minutes" (Stelte). To avoid passing the infectious disease to his wife and children, he quarantined in his New York home's basement and continued to anchor his show Cuomo Prime Time from there. Two things from his sharing strike me the most. First, the pain the disease inflicts on your body is absolutely horrible; I wish for no one to ever catch the disease. Second, those are no small requirements in order to practice safe quarantine: you need to have a spare basement or bedroom in your home, someone to care for you, and still have an income by being allowed to work remotely. As I currently share a condominium unit with my colleague on campus, I often wonder where I should go if I need to be quarantined. Should I spend huge portions of my savings to rent a separate apartment? Will I be allowed to work remotely? What about people who can't afford a separate room? What about factory workers or service personnel who simply can't work from home and have probably lost their income due to lockdowns?

These questions about living and working conditions keep bringing me back to the descriptions of those conditions in the semi-autobiographical novel America Is in the Heart (1946), written by Filipino immigrant poet and fiction writer Carlos Bulosan. Being cruelly discriminated against and persecuted in America, the main character Carlos and his fellow Filipinos could only find jobs in crowded and poorly ventilated bunkhouses and could never afford rooms of their own. Their living situation is described in one scene: "one of the girls was in the bed with two men. The other girl was on the couch with two other men ... Six men were sleeping on the floor and three others sprawled under the bed" (America 132). In another scene, Carlos and five other friends have to share one small room, with "no bathroom, no closet, no window" (138). If they were alive today, it is highly possible that they would get infected with COVID-19 at work and cross-infect each other back home. Worse, losing all means of income and having no one to care for them, they would die a painful death from COVID-19 just as many poor people do today.

The case of the COVID-19 pandemic entails a critical understanding of the social nature of bodily illnesses: contracting a disease is not solely determined by a weak immune system but is co-determined by the larger environment one is in. One's income, work type, social status, ethnicity, and living and working conditions, among others, all play a part in the chances of one getting the disease and the treatment one will receive. Examining the entanglement between material matters and social forces is to make the "material turn" called for by ecocritics Serenella 
Iovino and Serpil Oppermann. The "material turn" is the search for new conceptual models that theorize

the connections between matter and agency on the one side, and the intertwining of bodies, natures, and meanings on the other side. These meanings can be social, political, cultural, symbolic, or (as biosemioticians maintain) 'natural', namely, connected to the way living matter organizes itself in auto-regulated patterns. (Iovino and Oppermann 450)

In other words, the turn to material is to see it not as a separate entity, but to see its inextricable connections with forces of politics, economy, science, culture, etc. Material matter should be taken "as a text, as a site of narrativity, a storied matter, a corporeal palimpsest in which stories are inscribed" (451). One research focus of material ecocriticism is to study how polluted waters (the material) tell stories of political gains, economic interests, and people's careless attitudes towards nature.

In her book Bodily Nature, Stacy Alaimo asks us to refuse to "see the delineated shape of the human as distinct from the background of nature, and instead focuses on interfaces, interchanges, and transformative material/discursive practices" (142). She proposes the concept "trans-corporeality," which refers to "material interconnections of human corporeality with the more-than-human world" (2). She uses the prefix trans to underscore "movement across different sites" (2) and "acknowledges the often unpredictable and unwanted actions of human bodies, nonhuman creatures, ecological systems, chemical agents, and other actors" (2). This means that the human body is not a fenced-off entity, but a site of transcorporeality where cultural, economic, political, and biological forces intersect.

A more concrete example of trans-corporeality is Richard Lewontin and Richard Levins's concept of "the pancreas under capitalism" or "the proletarian lung":

The conditions under which labor power is sold in a capitalist labor market act on the individual's glucose cycle, as the pattern of exertion and rest depends more on the employer's economic decisions than on the worker's self-perception of metabolic flux. Human ecology is not the relation of our species with the rest of nature, but rather the relations of different societies, and the classes, genders, ages, grades, and ethnicities maintained by those social structures. Thus, it is not too far-fetched to speak of the pancreas under capitalism or the proletarian lung. (37)

Lewontin and Levins's argument that human ecology is the relation of many social forces is to see human bodies as a site of trans-corporeality. Seeing from this lens, workers catching lung diseases is not only a biological but also a social issue, as the inhumane working conditions that result in lung diseases is produced and 
perpetuated by class oppression. "The proletarian lung" demonstrates that social injustice is written on the physical body in terms of illnesses.

The above-discussed theories enable me to view bodies and the cultural, economic, and political environment they are in as entangled: social injustices are registered on people's bodies. This is the framing device underlying my discussion of Carlos Bulosan's America Is in the Heart. The author himself was hospitalized between 1936 and 1938 in Los Angles from serious health problems including tuberculosis (Cabusao 47). Bulosan was in bad shape when he was writing America Is in the Heart as described in a letter to Dolores S. Feria in 1942: "my body decays and slowly crumbles to uselessness" (Falling Light 204). He had also experienced acute hunger: in another letter to Dolores, he mentioned he used to sit in her apartment waiting for something to eat (203). Perhaps his own experience with illnesses and hunger made him more sensitive to these bodily pains. His novel America Is in the Heart abounds with hunger, illnesses, injuries, and dead Filipino bodies. The pervasiveness of these bodily pains across geographical bounders makes it clear that these are not individual health issues but are collective and systematic issues. I argue that Bulosan uses tuberculosis, syphilis, hunger, injuries, and dead bodies to expose and critique colonialism, racism, sexism, and class oppression in both the Philippines and the US. I also point out that tuberculosis, syphilis, and hunger could be defined as "slow violence," bringing into light the hidden costs of social injustices, while "quick violence" like injuries and death is a highly visible act, forcing readers to understand the violence surrounding the Filipino migrant experience without any sugarcoating.

America Is in the Heart is arguably Bulosan's most celebrated and studied work. However, scholars tend to focus on the sociocultural aspect of the novel. ${ }^{1}$ Few works study the material aspect-bodies, illnesses, injuries, etc. Thus, an interdisciplinary work that applies ecocriticism to America Is in the Heart bridges the gap between the cultural and the material and helps to understand the entanglement of the much-studied social forces and less-studied material bodies. Recently, literary scholar Kelly Adams has opened the dialogue between postcolonial theories and environmental theories in her article "Postcolonial Environmentalism in Carlos Bulosan's The Cry and the Dedication." ${ }^{2}$ Applying Rob Nixon's concept of "slow violence" to Bulosan's The Cry and the Dedication, she argues that Bulosan uses several imaginative strategies to make visible the slow ecological degradation in the Philippines due to colonial exploitation. Following her lead, my study shows how Bulosan uses bodily pains to make evident slow and quick violence incurred by colonialism, racism, class oppression, and sexism.

America Is in the Heart starts by recounting Bulosan's peasant youth in the Philippines under the name Allos. Allos grows up on the farm as the youngest son 
in a poor peasant family in rural Philippines. He has a hard childhood, starting work in the fields and doing chores at the age of five. His mother lives separately in a barrio in Binalonan, earning money by bartering food and selling salted fish. His father buys into the American appeal of universal education, so much of the family income goes to support Bulosan's brother, Macario, who is in an American-built public school. The family mortgages all the land they possess to pay for Macario's school fees. Eventually, they lose their land due to lack of money and unfair usury practices, which plunges the whole family into abject poverty.

To escape the hardships as a Filipino farmer and to avoid marrying a farm girl who forces herself upon him, Allos sails to the United States, the dreamy land of equality and prosperity. He first lands in Seattle, Washington. A hotel owner takes advantage of his inexperience and sells him for five dollars to a Filipino contractor. Allos, now called by his Christian name Carlos, has to undertake the most menial work to survive, first in Alaska fisheries and later in West Coast agriculture. He encounters countless instances of racism and exploitation from white people, coming to an awareness that "it was a crime to be a Filipino in America" (America 121). Carlos eventually becomes a labor activist and writer, dedicated to the building of an equal society. This novel is generally considered as reflective of the experience of the Filipino Americans of its time. Susan Evangelista claims it as "a collective history of the West Coast Filipino migrant workers during the Depression" (27).

To better grasp the multiple layers of social violence on the Filipinos articulated in the novel, it is vital to be attentive to the intertwined histories of the Philippines and America. The Philippines had been Spain's colonized land for centuries. After the Spanish-American War in April 1898, Spain ceded the Philippines to the United States. Filipinos subsequently became colonial subjects under US rule. In Cynthia Tolentino's discussion on Filipino self-representation against US colonist policy, she argues that one of the key assumptions of the US colonial project in the Philippines was that Filipinos was made up of uncivilized tribes, needing white men's tutelage. This assumption justified the colonization of the Philippines with notions of duty and protection (Tolentino 386).

In America, as agriculture became a large-scale enterprise needing a large amount of labor in the early twentieth century, farmers began recruiting Filipino migrant workers. Filipinos comprised much of the seasonal labor from California to Oregon, Washington, and Alaska, where they either harvested fruits or vegetables, did domestic work, or worked in canneries. In 1920, the West Coast of the United States alone had an estimated 5,60o Filipinos. By 1930, this number had skyrocketed to 45,372 ("Filipino Immigrants"). In his study on the historical background that shaped Bulosan as a writer, E. San Juan, Jr. records that Filipino workers in America up to 1934 were designated a status of nationals without citizenship rights 
(“Internationalizing" 131). Filipinos were exempt from United States immigration laws that excluded waves of immigrants from Asia, but they were not entitled to the same rights as American citizens. They were basically "exiles, deracinated subjects, displaced colonials, sojourners not settlers" (131).

Following the passage of the Tydings-McDuffie Act of 1934, the Philippines was granted Commonwealth status and a ten-year transition period to independence. Filipinos subsequently became aliens in America and immigration from the Philippines was restricted to only fifty persons per year. With the Japanese invasion and occupation of the Philippines during World War II, the gradualist path to independence was disrupted-Filipinos had to fight alongside their former colonizers. After the war, according to the terms of the Philippine Independence Act, the US recognized the independence of the Republic of the Philippines on 4 July 1946, though it still retained large military bases in the Philippines.

Carlos Bulosan left the Philippines and moved to the US West Coast in 1930 in a time when America was wrecked by the Great Depression and the market was flooded with unemployed workers. The experiences of being a working-class Filipino in both the Philippines and America and the status of Filipinos in America as nationals without any citizenship protections provided him with unique insights on the despair that surrounded a working-class Filipino in that era. He occupied a marginalized and oppressed place in both countries. In America Is in the Heart, these social injustices are reflected on physical bodies.

\section{TUBERCULOSIS}

Who has a higher risk of contracting tuberculosis? It would be people who live or work in prisons, homeless shelters, or nursing homes, because the risk of the disease is higher wherever there is overcrowding and poor ventilation. Tuberculosis represents "slow violence," which Rob Nixon defines as "a violence that occurs gradually and out of sight, a violence of delayed destruction that is dispersed across time and space, an attritional violence that is typically not viewed as violence at all" (19). Because of its nature, Nixon argues that it presents "formidable representational obstacles that can hinder our efforts to mobilize and act decisively" (19). Suffering from tuberculosis is unlike suffering from more conventional violence, such as exploding heads or bleeding noses, which is immediately sensational. The slow dying from tuberculosis rarely rouses public sentiment or warrants political intervention. I argue that by depicting how tuberculosis affects working-class Filipinos disproportionately, Bulosan makes his readers recognize its violence and condemn its racist and colonialist origins. 
Carlos himself contracts tuberculosis in America. Due to the conspiring forces of racism and class exploitation, he has long suffered from poor working and living conditions. For example, when he first arrives in America, he is cheated to work in the fishery industry of Alaska by a white proprietor. Carlos describes their working place as "unfit for human habitation" (America 101): the lighting system is bad and dangerous for their eyes and the workers toiling in semi-darkness are severely affected by the strong ammonia from the machine. Carlos works in the section called "lye wash" (102), where he washes beheaded fish in water containing lye. I want to call attention to the Filipino fishery workers' vicinity to two hazardous chemicals: ammonia and lye. High levels of ammonia and lye can irritate and burn the skin, mouth, throat, and eyes; very high levels of ammonia and lye can damage the lungs. In this case, Filipinos' direct contact with two toxic chemicals without any protection represents slow violence that Filipino fishery workers are suffering from.

When Carlos reunites with his brother Macario, they find that they are unable to rent a room in decent communities due to racism. The only place that they can rent a room is in the red-light district where "pimps and prostitutes are as numerous the stars in the sky" (134) and "suicides and murders are a daily occurrence" (134). When they can't afford hotels, they have to sleep in the five-cent theatres with "monstrous rats" (138) that run over their feet when the lights go off. In another place that accommodates homeless people, Carlos only gets a small part of floor to sleep on. He has to endure the "musty smell" (154) of his blanket and "the stench of the unwashed bodies of men" (154) around him. Examples of such over-crowded and unhygienic conditions permeate Carlos's life. Bulosan describes this life as a "beastly struggle for existence" (138). The modifier beastly doesn't only show how hard this struggle is-it also suggests that working-class Filipinos are indeed reduced to beasts.

Inevitably, this lifestyle takes its toll on Carlos. He is hospitalized because of tuberculosis, forced to go through four operations to arrest its contagion. After the last operation, he is told that he has no more rib on his right side. Even the operations can't stop him from dying. The doctor declares he has at best five years to live. He provides an appalling picture of himself: "I could no longer work with my hands; the right was partially paralyzed. My left leg was shrunken and stiff" (260). Through the details of Carlos's operations and the descriptors such as paralyzed, shrunken, and stiff, Bulosan demonstrates that slow violence is just as vicious as conventional violence.

Carlos's friend Manuel, working as a janitor in a big apartment in Hollywood, is underpaid by his white employer so he is forced to do "the work of two men" (134). His health slowly deteriorates due to hard work. Manuel is hospitalized with 
tuberculosis and eventually dies, while his wife runs away (134). Poco, a migratory Filipino worker in the beet field in Montana also contracts tuberculosis (150). In Pismo Beach, Carlos and Mariano sleep on the floor of a small cabin occupied by two fellow Filipinos. One Filipino also dies from tuberculosis in winter (174). It is no coincidence that Bulosan writes about these tubercular Filipinos; it is his strategy to lump together numbers of tubercular Filipinos to make us attentive to the slow violence that has left its marks on Filipino bodies.

It is not only in America where Filipinos catch tuberculosis; they also die from it in the Philippines. Bulosan records multiple sites of tuberculosis to expose multiple social violences that contribute to its infection. Carlos's brother Luciano, serving with the Philippine Scouts in Camp Stotsenburg, a native detachment of the United States army, fights for America in Europe for three years. During the war, Luciano contracts a serious disease, which turns out to be tuberculosis. After he comes back to the Philippines and becomes the Mayor of Binalonan, he spends most of his hard-earned pension on doctor's fees and eventually dies young. It is such a pity that this promising man-who knows how to operate machines, has high political ambitions, and always encourages his brother to read more-doesn't even get a chance to serve his own country, dying so young because of the slow violence inflicted by America's colonization.

Had Luciano died in the war, it would be easier to see him as a victim of colonialism. However, Nixon in Slow Violence makes clear that war casualties should include those who "don't fit the photographic stereotypes, casualties that occur long after major combat has been concluded, casualties whose belatedness and dispersal make them resistant to dramatic packaging" (200). Luciano is a discounted war casualty for America. Though discharged from the army, his eventual death from tuberculosis does reveal the hidden cost of being a colonial subject. There may be numerous other Filipinos who die of tuberculosis after returning to the Philippines. Since the slow violence of the war happens gradually and spans across place, these people may be unrecorded and unremembered as war casualties for the US. Thus, Bulosan's recording of a tubercular veteran is significant in bringing into light the aftermath of American colonialism in the Philippines.

When hospitalized, Carlos once desperately asks,

I became intensely aware of the room: the four gray walls that seemed to fall upon me, the antiquated furniture, ugly and dark, and the utter dullness of everything around me. And I became aware of the presence of other things that had seemed inconsequential before: why Macario-why all of us were constantly hounded by the terrible threat of unemployment and disease. (America 226) 
Why are Filipinos constantly haunted by disease? This is not as much a question as Carlos's protest. Because Bulosan explicitly takes issue with "disease," I argue that he is aware of the linkages between Filipinos catching tuberculosis, American colonialism in the Philippines, and exploitation and racism in the US. Catching tuberculosis is no longer an individual issue but a collective experience of colonialism, racism, and class exploitation registered on Filipino bodies.

\section{SYPHILIS}

Syphilis is another underrepresented form of "slow violence" as it slowly eats away at people's health. Working-class women, including the wives or partners of the Filipino characters, frequently die from syphilis in this novel because they have no way to make money other than going into prostitution.

A working-class white woman named Marian kindly takes Carlos in when Carlos is fleeing from prosecutors. She empathizes with the oppression Carlos suffers because she also lives a life of hardship—she "had washed dishes all over California" (211). Desperate to have someone to love, she tells Carlos that she will work for him and even support his education. In the following days she would disappear at night and come back in the morning with food and money. It is not until she suddenly collapses when Carlos learns that she has contracted syphilis-all the money she brings back is earned through prostitution. In another case, after the Filipino Luz suddenly dies, his Mexican wife has no other means to support herself but to go into prostitution. In the end, she also dies of syphilis (136). These women's workingclass status is compounded by sexism that permeates their life. It is safe to conclude that prostitution and the illnesses it incurs becomes the only option for Marian and for Luz's wife. However, since the slow death from syphilis is not sensation-driven, victims of syphilis, which originates from class oppression and sexism, become unimportant and overlooked.

\section{HUNGER}

A third kind of slow violence is the tormenting but internal feeling of hunger. Bulosan portrays a land of starving peasants as an effect of colonialism in the Philippines. As the land laws under America's colonial administration are set to defend the interests of large corporations and absent landlords, many peasants are dispossessed of their land and barely make a living. Allos recalls that many peasants are "starving" (36) and the "obsession for food" (36) becomes a familiar feeling to 
him. His mother often starves herself so that her children can have something to eat (281).

Hunger follows Filipinos to America. Landing in Seattle with little money, Carlos is "hungry and afraid to go out" (99). On Carlos's journey from Sunnyside to Stockton in search of his brothers, he has nothing to eat for two days (117). In his first time in Los Angles, Carlos has nowhere to go but to sleep on a wooden bench. All he feels is being "hungry and cold" (128). After he takes temporary shelter in the church, he wakes up feeling "as though a beast were tearing at the walls of my stomach" (128). He is hungry again. When Carlos finds his brother Marcario and several fellow Filipinos in Los Angles, all of them live a poverty-stricken life. They sell everything but are still unable to make ends meet as they are long unemployed. Desperate days come. Carlos experiences "aching hunger" (137) and feels that "every dawn was the opening of starvation and exile" (137). He becomes acquainted with Estevan, a Filipino who wants to become a writer and is described as "starving" and falls upon food like a dog (139). After Macario's friend Nick gives the last remaining money to his brother Jose for a girl's abortion, Carlos and his brother are thrown into the street. Then "days of hunger and pain followed" (140). Even having been in America for years and worked numerous jobs, Carlos is still haunted by hunger.

I am indebted to Kelly Adam's point that Bulosan uses the repetition of the words hunger, hungry - and I add, starving - throughout the text to demonstrate the visceral effect of slow violence on Filipino bodies (594). I further add that Carlos and his fellow Filipinos are keenly aware of this slow violence on them. In a heated discussion with Carlos on Filipinos' predicament, Carlos's brother Macario declares: "It is a great wrong that anyone in America, whether he be brown or white, should be illiterate or hungry or miserable" (188). Viewing being "hungry" as "a great wrong" indicates that they know that the origin of their hunger goes back to systems of social injustices.

\section{INJURIES}

Contrary to slow violence, injuries and death are bloody, instantaneous, explosive, and spectacular, creating a forceful critique of class oppression and racism. In the Philippines, the hardships of peasantry have left every member of Carlos's family injured. As Allos's family loses their land to unfair usury practices, the whole family has to work harder. During rainy seasons, Allos, together with his father and brother, has to work under heavy rain, suffering from aching bodies (16). Due to a life of toil, his father is described to have "ugly, dark hands" (55), while his

mother's hands are "big-veined, hard, and bleeding in spots" (22). Employing the 
quoted descriptive language, Bulosan makes the often-ignored body part-scarred hands-speak volumes about the hardships of peasant life.

To make ends meet, Allos picks coconuts from the tall coconut trees in the neighborhood, which is a very dangerous job. He falls from the trees twice, breaking his legs and arms and having to lie in bed for months $(17,45)$. While working on the construction of the highway, he is swept into the water and almost dies (31). Dispossessed of all his land, Allos's father walks fifty kilometers to the Pangasinan provincial capital to seek justice. When he comes back home, he is defeated in spirit and injured in body-his feet bleed from all the walking (28). It is the bleeding feet, broken legs, and scarred hands that foster Allos's political consciousness-he becomes aware of poverty and degradation surrounding them, and years later these hardships become driving forces to Carlos.

In America, he is also subject to the same ruthless class exploitation compounded by racism. In Carlos's first job in the fishery factory in Alaska, one cutter has his right arm slashed off by the cutting machine due to the poor lighting in the factory. The horrifying sight of "his arm floating down the water among the fish heads" (102) forces the readers to recognize the danger in these inhumane working conditions. In the gambling houses where Filipinos usually gather after work, being killed is a daily occurrence. Once Carlos is drinking tea in a gambling house, suddenly a Chinese man comes out of a back room with a gun and shoots a Filipino man who is standing by a table (116). In another gambling house, two police detectives go into the place and shoot a young Filipino man for no reason. After their hideous act, they simply call an ambulance, dump the dead Filipino man into the street, and leave, "untouched by their act, as though killing were a part of their day's work" (129). The ease of white men's killing juxtaposed with the horror of the dead Filipino man's body highlights the power imbalance between white people and Filipinos, which has registered on Filipino bodies.

Images of scarred hands also abound in Bulosan's America. Carlos is once viciously beaten by two white policemen for the sole reason of being a Filipino:

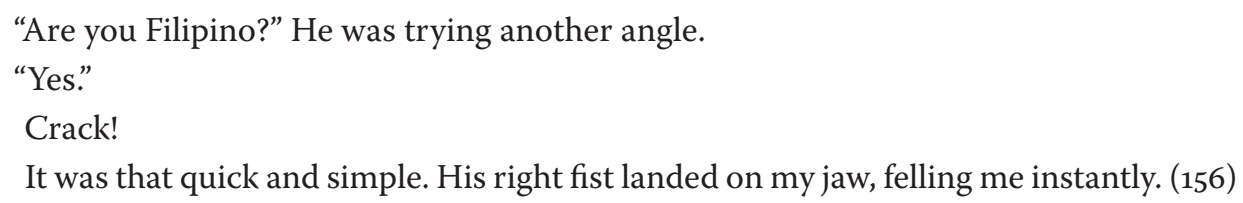

This succinct conversation between the white policemen and Carlos points out the fact that it is pure racism that incurs the following beating. Making a narrow escape, Carlos has his hands smashed and bleeding. Working in an ice plant, Carlos finds his hands "brittle and dead with the cold" (169). When Carlos's 
brother Macario leaves for Spain to join the war, Carlos notices that Macario's hands are "hard and calloused" (241), "ugly and twisted" (241), and "cracked and bleeding" (241). When meeting another brother Amado in Bakersfield, Carlos notices the "length of scar on the back of his hands" (296). Images of scarred hands belonging to different people in the novel show that these hardships are a universal experience of being a Filipino in America.

Being a Filipino also represents a particular sexual threat to white people, which leads to injuries on their genitals and other beatings. The racist perceptions of Filipinos at the turn of the twentieth century are well documented in The Forbidden Book: The Philippine-American War in Political Cartoons, a collection of political cartoons and photographs about America's involvement with the Philippines. In the collection, Filipinos are frequently primitivized. For example, in Victor Gillam's 1899 cartoon captioned “The White Man's Burden” on the cover of Judge magazine, John Bull and Uncle Sam are seen climbing a rocky mountain toward a figure labelled "Civilization," with Uncle Sam carrying four racist caricatures on his back"Filipino," "Porto Rico," "Cuba," "Samoa," and "Hawaii"- the Filipino caricature topless and waving a hammer (25). The Filipino caricature's nudity, messy hair, terrifying facial expression, and weapon-carrying serve to visually testify to the wildness and savageness of Filipinos, legitimizing white men's tutelage to them. In the 1904 World's Fair in St. Louis, Missouri, the primitive image of Filipinos was again enhanced by having Igorot people, a Filipino indigenous group, exhibit their nude bodies that were only covered by G-strings and showed a distorted version of their customs - they were made to butcher dogs and eat the animals daily during the fair (Allan). Filipinos were represented as both savage and erotic. Later, when waves of Filipinos migrated to America in the early and mid-twentieth century, they were sometimes associated with African American males as sexual predators, while other times with Asians as servile workers (Santa Ana 78). White racists projected African American males as hypersexual, threatening to contaminate the purity of the white race by having sexual intercourse with white women. This sexualized stereotype served as justification for the regulation on African American bodies (apartheid, miscegenation laws) and violence on them (antiblack riots, lynching). Asian Americans, on the other hand, are often perceived as obedient and submissive, objects of economic exploitation, exclusionary immigrant laws, and wartime imprisonment. Filipinos found themselves "caught in a racial arrangement with the overemotional and oversexed black male subject on one end and the emotionally inscrutable and docile East Asian on the other" (79). Scholar Amanda Solomon Amorao further links the sexualized representation of Filipinos to the granting of Philippine independence. She argues that as the need of labor contracted since the Great Depression, the representation of Filipinos shifted from colonial subjects needing tutelage to "lascivious threats to white women" (Amorao 228) and "potential rapists frequenting licentious taxi dance halls" (228). Thus, 
Filipinos' perceived primitive sexuality became a symbol of "racial, national and evolutionary difference that drove the granting of Philippine independence" (228). This kind of sexual construction has dire consequences for Filipinos. In America Is in the Heart, the consequences are reflected on the injuries Filipino men receive.

While organizing farm workers in San Jose, Carlos, Millar, and Jose are abducted by a gang of racists. In a symbolic way to destroy Filipinos' sexuality, the white racists cruelly tear off Jose's clothes, tie him to the tree, and burn the hair between his legs. They go on to beat Carlos almost to his death and smash his testicles (America 208). Isaac argues that the implicit castration in burning Jose's hair and the explicit castration in smashing Carlos's genitals can be seen as white people's assertion of their control over Filipinos' sexual and political agency (132). Filipinos who are found to be with white women are also cruelly beaten. One Filipino student, Alonzo, lives with a white divorced woman. White detectives break into their apartment, slap Alonzo ruthlessly, and throw him into jail (136). Another Filipino and his white wife are refused service at a diner. When he begs food for his crying baby, the white proprietor strikes him viciously. When the Filipino fights back, he receives more beatings from other white men (145). For white racists, injuring Filipino bodies serve to keep Filipinos in their place, away from white women.

My final point in this section is that the author's language shows his awareness of the interconnectedness between bodily illness and injuries and social injustice. In the first part of the book, recalling how the peasants have been the victims of ruthless exploitation since Spanish colonial rule, Bulosan describes, "the cancer of exploitation became intolerable" (23, emphasis supplied). When peasants finally come out with their demands, Bulosan comments, "These sporadic revolts and uprisings unquestionably indicated the malignant cancer that was eating away the nation's future security" (24, emphasis supplied). In America, long being in an environment that is infused with violence, Bulosan laments: "It took me a little lifetime to fight against the death of myself, to fight the slow decay that devoured me like cancer" (152, emphasis supplied). Death, decay, and cancer can both be taken metaphorically as they refer to consequences of social injustice and literally as the fact that social injustice causes bodily illnesses. Bulosan's language of disease and injuries traverses many of his works. For example, in Bulosan's famous poem "If You Want to Know What We Are," he claims that to know Filipinos, one should observe "the bloody club smashing heads, the bayonet / penetrating hallowed breasts, giving no mercy" (594), "the / bullets crushing upon armorless citizens" (594), "the tear-gas choking the weakened lung" (594), "the lynch / trees blossoming" (594). In the poem, numerous suffering bodies - smashed heads, penetrated breasts, bodies shot by bullets, choked lungs, and lynched bodies-become the defining experiences of migrant Filipinos. Bulosan knows that social injustice lies at the core of these suffering. 


\section{HEALING}

Filipino bodies mark social injustice, yet they also mark healing and resistance. Nature provides nourishment to Filipino characters in the novel. In the Philippines, Allos's family toils on their four hectares of land, and the land in turn provides them with both basic subsistence and emotional nurturing. The land is well-managed by Allos's father, providing enough food to the family for many desperate years. Allos starts to work on the land at a young age. Though farm work makes their backs ache and their hands scarred, nature always offers consolation. Allos breathes not the polluted air, but the smell of "fresh upturned earth in the air and the bitter smoke of burning grass" (America 3). He sees not bricks and barren lands, but the long and broad leaves of the corn "upraised to heaven in gentle supplication, moving slowly with the night breeze toward the west, as though they were making the sign of the cross and bowing to the wet earth in reverence" (27). He hears not the blowing of car horns, but the quails singing their mating songs between the growing rows of corn. The sweetness and peace of the natural surroundings console the bodily exhausted Bulosan family. After work, Allos's father and brothers would talk about the farm for hours (12). Allos's family is poor, but he thinks one redeeming quality in their poverty is the humanity that grows in them, which is "as boundless as this green earth" (10).

At the end of the novel, the land becomes the embodiment of hope that sustains Carlos. Carlos's hope for a democratic America is not uprooted by the violence he experiences; instead, he finds "with astonishment that the American earth was like a huge heart unfolding warmly to receive me. I felt it spreading through my being, warming me with its glowing reality" (326). Carlos's struggle to take root in America is symbolized as "digging my hands into the rich soil here and there" (326). Therefore, Bulosan suggests that Filipinos may not initially take root in America, but over time they will flourish in new soil.

Closely linked to the land are trees and rivers, which, like the land, are key to human survival. Trees save Carlos twice. Once, Allos falls from the top of a coconut tree, breaking one leg and one arm. His father brings home an albolario, who is a folk healer. The man burns many leaves of trees and rubs the ashes mixed with oil over Allos's body. Though Allos thinks the doctor is a little better than a witch doctor, his bones actually begin to knit together and in two months he is able to move his arm and leg (45). Later in America, when Carlos is affected with tuberculosis, he goes through four major operations and has to stay at the hospital for two years. Carlos is relocated to a ward that is near the only tree in the hospital. Surprisingly, no one in this ward or in the other wards near the tree dies and, when a patient is transferred to the porch, he recovers rapidly. Carlos and other patients develop an attachment to the tree, imitating: "[W]e felt we were alive because of it. 
When the slight breeze rustled its leaves we got up from our beds and stood near it. I held onto faith although the doctors disputed it. Let them. I held onto the tree, as though its leaves protected me from death" (250). In both cases, trees bring back life and vitality.

The river also offers comfort to human beings. In Seattle, Carlos hires himself out to a small farmer, helping pick apples. At that time, there is ruthless persecution of the Filipinos throughout the Pacific Coast. One day, the employer's house is attacked and burned. Carlos, together with another Filipino named Julio, flees. They walk without rest for a whole night. Finally out of danger, they encounter the Yakima River. Hearing the "sudden tumult" of the river (111), Julio and Carlos run frantically towards it and throw themselves into the river. In this case, the cool and clear water wash away their bodily exhaustion.

At last, it is Carlos and his fellows' faith in building a democratic society that help them conquer bodily pains, transforming them from passive receivers of bodily illnesses and injuries into active history-makers. Carlos's fellow Filipino activist José has his leg cut off while fleeing from railroad detectives and is left hopeless in the hospital. Later, when Carlos accidentally bumps into him at Filipino editor Pascual's house, Carlos is surprised to find that José springs to life working actively both as an organizer for an independent Filipino union and promoter and later editor for the newspaper Pascual owns. José actively takes part in many progressive activities. When pea pickers strike in Pismo Beach, José ventures to be the chairman for the meeting. Later, José and Carlos work together to advertise The New Tide, a magazine that documents the social reality for the Filipinos. Despite the trauma of losing one leg, José continues to fight for the Filipino trade union because he believes it is "an assertion of our right to be human beings again" (186). The absence of one leg no longer marks the pain received, but represents José's resistance to injustices and to his passive status in America.

In two of Carlos's darkest illness-ridden moments in life, he is also empowered by his faith in fighting for a democratic society. The first dark hours come when he is hospitalized with tuberculosis. Confined to bed, he can only draw nourishment from books brought by the Odell sisters. Through reading, he comes into contact with many democratic writers who harbor a similar faith in creating an equal society. For example, Carlos is captured by American poet Hart Crane's passionate words, which, as Carlos understands, comes from Crane's determination to find "a faith strong enough to challenge modern chaos" (245). Their writings kindle Carlos's faith in fighting for Filipino rights in America. As he puts it: "These sensitive writers reacted to the social dynamics to their time. I, too, reacted to my time" (246). I call attention to the assertiveness in Carlos's tone. By claiming that he will react to 
social injustices in his time, Carlos projects himself not as a passive sufferer, but an active history-maker.

I further add that, at this dark moment, it is not only the faith in fighting for justice in the US but also the faith in fighting for justice in Philippines that assuages Carlos's bodily pains. In the hospital, Carlos receives a letter informing him that his brother died of tuberculosis. It makes him suddenly remember all the sufferings of his family in the Philippines and he promises to make them come to live in his writing. Despite his paining body, this commitment gives him "a strange courage and a vision for a better life" (57).

The next dark hour is when Carlos is informed by the doctor that he has only five years left. His health is in a very bad condition: the injured right hand is partially paralyzed, the left leg is shrunken and stiff, and his lungs are greatly impaired (260). Upon hearing the news, terror fills him. However, this terror is soon replaced by his determination to make the most use of his last years through writing to expose injustice. In the following years, Carlos spares no efforts fighting for his faith in an equal society for Filipinos: he writes and publishes about Filipino life, organizes Filipino union movements, and educates fellow Filipinos on American history and the origin of democracy. In both cases, bodily pains, once conquered by mental power, become signs of the strength of mind.

At the end of the book, Carlos reiterates how strong his faith is: "[N]o one could destroy my faith in America that had sprung from all our hopes and aspirations, ever" (327). I emphasize that as Bulosan exposes bodily sufferings in both the Philippines and the US and how Carlos will write for Filipinos in both countries, this "America" is not limited to the US as the country, but symbolizes an equal and free society in both the Philippines and the US. As conveyed through the title of this book, this ideal vision of a society, as embodied in "America," is always cherished in his heart.

Reflecting upon the violence and tragedies that surround him, Carlos once laments: "I was a part and a product of the world in which it was born" (152). In a similar vein, I argue that Filipinos' bodily pains are also part and product of the world they are in. Bulosan's representation of bodily pains offers a critical language against social injustices of which bodies are part and product. Among the bodily pains, tuberculosis, syphilis, and hunger are hardest to discern. The elusiveness of these pains contributes to the perpetuation of slow violence on Filipinos in both the Philippines and the US. Bulosan records the large numbers of the affected and the pain on each of their bodies to bring into light the hidden cost of colonialism, racism, sexism, and class oppression. On the other hand, Bulosan's portrayal of images of injured or dead Filipino bodies such as cut legs and arms, smashed genitals, and scarred hands force us to directly face the bloodiness of labor exploitation and 
racial violence in both countries. In this way, Bulosan makes us attentive not only to the visible violence, but also to the slow violence that might has gone unobserved. Finally, Bulosan demonstrates where comfort and hope of resistance lie. Land gives Filipino migrants psychological grounding and embodies the hope that although they have yet gained a footing, they will eventually take root in this land. Trees and rivers also provide comfort to human beings. In addition, Carlos and his fellow Filipinos' faith in building a democratic society not only assuages their bodily pains, but also transform them from passive receivers of bodily illnesses and injuries into active fighters.

Lastly, I would like to return to the case of COVID-19 mentioned in the beginning of this article. The world is ravaged by the pandemic right now. As demonstrated here, one's experience with the disease is codetermined by the virus and the social environment one is in. Thus, it is critical for us to be attentive to the uneven impact of the pandemic on marginalized groups due to social injustices that predate this pandemic. 


\section{Notes}

1. In his article "Excavating the Bulosan Ruins: What is at Stake in Re-Discovering the AntiImperialist Writer in the Age of US Global Terrorism?" published in Kritika Kultura 23, E. San Juan, Jr. argues that "The immigrant-assimilationist paradigm becomes the Procrustean bed into which Bulosan's texts are forced" (159).

2. See Kelly Adams's whole article in Interdisciplinary Studies in Literature and Environment, vol. 22, no. 3, 2015, pp. 582-601. 


\section{WORKS CITED}

Adams, Kelly. "Postcolonial Environmentalism in Carlos Bulosan's The Cry and the Dedication." Interdisciplinary Studies in Literature and Environment, vol. 22, no. 3, 2015, pp. 582-601.

Alaimo, Stacy. Bodily Natures: Science, Environment, and the Material Self. Indiana UP, 2010.

Allan, Greg. "Living Exhibits' at 1904 World's Fair Revisited." NPR, 31 May 2004. https:// www.npr.org/templates/story/story.php?storyId=1909651. Accessed 1 Nov. 2020.

Amorao, Amanda Solomon. “The Manong's 'Songs of Love': Gendered and Sexualized Dimensions of Carlos Bulosan's Literature and Labor Activism." Reflections on Carlos Bulosan and Becoming Filipino, special issue of Kritika Kultura, no. 23, 2014, pp. 221-235.

Bulosan, Carlos. America Is in the Heart. U of Washington P, 1977.

--. "If You Want to Know What We Are." American Working-Class Literature: An Anthology, edited by Nicholas Coles and Janet Zandy, U of Pittsburgh, 2012, pp. 592-594.

--. Sound of Falling Light: Letters in Exile, edited by Dolores S. Feria. U of the Philippines P, 1960, pp. 203.

Cabusao, Jeffrey Arellano. "Bulosan, Carlos." Literature and Politics Today: The Political Nature of Modern Fiction, Poetry, and Drama, edited by M. Keith Booker, Greenwood, 2015, pp. 46-47.

Evangelista, Susan. Carlos Bulosan and His Poetry: A Biography and Anthology. U of Washington P, 1985.

"Filipino Immigrants." Immigration to the United States. https://immigrationtounitedstates. org/497-filipino-immigrants.html. Accessed 1 Nov. 2020.

Ignacio, Abe, et al. The Forbidden Book: The Philippine-American War in Political Cartoons. T'Boli Pub., 2004.

Iovine, Serenella, and Serpil Oppermann. "Theorizing Material Ecocriticism: A Diptych." Interdisciplinary Studies in Literature and Environment, vol. 19, no. 3, 2012, pp. 448-460.

Isaac, Allan Punzalan. American Tropics: Articulating Filipino America. U of Minnesota P, 2006.

Lewontin, Richard, and Richard Levins. Biology Under the Influence: Dialectical Essays on Ecology, Agriculture, and Health. Monthly Review P, 2007.

Nixon, Rob. Slow Violence and the Environmentalism of the Poor. Harvard UP, 2011.

Santa Ana, Jeffrey. "Emotional Labor of Racialization: Carlos Bulosan's Anger as a Critique of Filipino Alienation in America." Journal of Asian American Studies, vol. 19, no. 1, 2016, pp. 75-100.

San Juan, E., Jr. "Excavating the Bulosan Ruins: What is at Stake in Re-Discovering the Anti-Imperialist Writer in the Age of US Global Terrorism?" Reflections on Carlos Bulosan and Becoming Filipino, special issue of Kritika Kultura, no. 23, 2014, pp. 154-167. 
--. "Internationalizing the US Ethnic Canon: Revisiting Carlos Bulosan." Comparative American Studies, vol. 6, no. 2, 2008, pp. 123-143.

Stelte, Brian. "Chris Cuomo shares COVID-19 experience: 'The beast comes at night." CNN Business, 3 Apr. 2020. https:/edition.cnn.com/2020/04/o2/media/chris-cuomocoronavirus-reliable-sources/index.html. Accessed 1 Nov. 2020.

Tolentino, Cynthia. "In the 'Training Center of the Skillful Servants of Mankind': Carlos Bulosan's Professional Filipinos in an Age of Benevolent Supremacy." American Literature, vol. 80, no. 2, 2008, pp. 381-406. 